\title{
TERMINOLOGICAL AND HISTORICAL BACKGROUND OF GUERILLA MARKETING AS A MARKETING COMMUNICATION STRATEGY
}

\author{
Iveta Balážiová', Lucia Spálová2
}

\begin{abstract}
This article deals with guerilla marketing and/or guerilla marketing strategy on the background of military attack strategies. The aim of this article is to grasp guerrilla marketing in a broader context, starting from the marketing and communication strategy, which is historically and terminology inspired by the military strategy of guerrilla attacks and/or by military strategy in general. The theoretical study is a meta-analysis of five scientific publications dealing with the overlays of military strategies and marketing to identify useful marketing and communication strategies. Guerilla marketing as an offensive-defensive strategy present among the attack strategies and it is described as a way for small and weaker businesses to compete with large corporations in the existing conflict and to act as challengers in the battle. An emphasis will be put on the primary characteristic of guerrilla warfare: it is a typical competitive struggle based on a series of small intermittent attacks and withdrawals.
\end{abstract}

Keywords: Guerilla marketing. Guerrilla warfare. Marketing strategy. Military strategy. Offensive strategy. Competitive struggle.

\section{Introduction}

Given that in our modern era of digitization, globalization and internationalization even the smaller companies enter the online environment, the increase of competition in the market environment is evident, resulting in a sort of mega competition among the businesses. Already at the end of the last century, Odgen (1999) claimed that the competition is bigger and more unpredictable than ever before. At present, his statement is even more true. A variety of creative marketing concepts are foregrounded, including guerilla marketing, the concept of which is based on the military strategy of guerrilla attacks.

In essence, guerrilla marketing is an offensive marketing strategy focusing on

\footnotetext{
Iveta Balážiová, Constantine the Philosopher University in Nitra, email: iveta.balaziova@ukf. sk, ORCID ID: 0000-0003-3896-0245

$2 \quad$ Lucia Spálová, Constantine the Philosopher University in Nitra, email: Ispalova@ukf.sk, ORCID ID: 0000-0002-2854-2069.
} 
overcoming the competition. Its aggressive and offensive nature and the attacks on the competitors are some of the inherent features of guerrilla marketing, which is also emphasized by Mohawk Paper Mills, Inc., (2006, in Gupta, Kaur, Kamboj, 2014) who define guerrilla marketing as an aggressive, highly targeted to subversive advertising campaign taking place on the street with the aim to create an unexpected and memorable connection between the product and its consumers. On the other hand, other approaches highlight competitiveness - and not cooperation - in the context of guerrilla marketing. In this context, Jay Conrad Levinson $(2011$, p. 7$)$ uses the term fusion marketing for guerilla marketing. This term reflects the cooperation of businesses with rival companies in the joint marketing efforts. A certain discrepancy can be noted in this approach, and its essence can be found in the sources describing guerrilla marketing in the context of military strategies. The main aim is to grasp guerrilla marketing in a broader context, starting from the marketing and communication strategy, which is historically and terminology inspired by the military strategy of guerrilla attacks and/or by the military strategy in general. The aim is to identify useful marketing and communication strategies using the principles of meta-analysis of five scientific publications dealing with the overlays of military and marketing strategies. Therefore, our efforts will result in an overview of the different marketing-communication strategies against the background of military strategies, which are generally useful in the marketing practice as a way for businesses to compete against their competitors.

\section{Marketing and military strategy: overlaps, inspiration, limits}

In the context of expanding competition, the companies are trying to find an effective way to intensify and streamline communication with consumers. There were multiple shifts in the development of marketing - from the production-based approach (1930s), through the selling-based approach (1930-1950s), to the marketing-oriented approach (1950s and later) where the main role is played by strategic thinking (Bozkurt, Ergen, 2014). Strategic thinking became the basis for planning the marketing strategy, which is defined as a tool for the transformation of business objectives into market activities (Lesáková et al., 2001). The marketing strategy adopted by a commercial company is a combination of intuition, expectations, knowledge and experience of the marketing managers, and it stands on compromises, confrontations and negotiations (Bogdan, Gabriela, Alina, 2008).

The meaning of the word "strategy" (gr. stratégos) carries military connotations and it denotes a military captain or general (Lesáková et al., 2001). Most of the names for marketing strategies were taken from military terminology (Bogdan, Gabriela, Alina, 2008), including the term "guerilla" whose strategic nature derives from an armed conflict (Spálová, Wojciechowski, 2017; Bigat, 2012). The term "guerilla" is of Spanish origin, and it denotes a "partisan" (Bozkurt, Ergen, 2014). It refers to the guerrilla methods of military attacks at a time when the poorly organized military groups - partisan units were attacked by a dominant enemy (Spálová, Wojciechowski, 2017). In other words, guerrilla warfare was a weapon of smaller and disadvantaged groups in a military conflict (Bigat, 2012).

In the marketing context, the term "strategy" along with the term "guerilla" refers to the relationship or similarities between the guerrilla marketing strategy and military warfare and/or military strategy. In this context, the market environment is seen as a battleground where the competitors occupy a certain market territory. A marketing strategy is the driving force of the company to vanquish its opponents. According to Ries and Trout (1997), the economic struggle between the competitors takes place in the mind of the consumers.

The existence of obvious similarities between military warfare and the market has led some authors (e.g. Bozkurt, Ergen, 2014; Ries, Trout, 1997, Kotler, Singh 1981; Bogdan, Gabriela, Alina, 2008) to find inspiration in military literature when determining the 
marketing strategies and their description using military strategies. Finding the parallels in discipline between the marketing strategy and military strategy and the descriptions for marketing strategies among those for military warfare led to interesting and generalizing results. It was found that an effective way of how to succeed in the market is to use one of the four strategies of the marketing war, namely: defensive, offensive, flanking and guerilla). These aforementioned strategies of marketing wars are considered to be basic in various literary sources (Odgen, 1999, Ries, Trout, 1997, Garsombke, 1987 in Bozkurt, Ergen, 2014) although some literature only mentions three basic types of military strategies: offensive, defensive and partisan. (Bogdan, Gabriela, Alina, 2008)

The suitability of military strategies in the marketing context is determined by the company's market share compared with its competitors. The principle of power plays an important role in the choice of strategy (Ries, Trout, 1997). Additionally, the selection of strategy is largely determined by business objectives. For example, if the aim of the market leader (which is determined by a majority market share) is to strengthen its position and increase dominance, the aims of the other fairly large companies concentrate on the efforts to increase this share.

Reflecting the above generalizing businesses objectives, the market leader should try to block the strong offensive moves of the competition while the challengers effectively apply the offensive strategies (Ries, Trout, 1997). Therefore, the defensive strategy seems to be appropriate for the market leader (Bozkurt, Ergen, 2014). The side attack strategy and/or flanking strategy is suitable for the companies focusing on certain segments in order to increase their profit margins (Bozkurt, Ergen, 2014, Ries, Trout, 1997). Finally, small businesses centered primarily on survival (Ries, Trout, 1997) use the guerrilla warfare strategy, which is intended for small and medium-sized enterprises (Bozkurt, Ergen, 2014). The guerrilla strategy seems to be the most controversial, and based on the opinion of Bogdana, Gabriela and Alina (2008), it is highly flexible and can be adapted to offensive and defensive operations.

Figure1: Offensive strategies

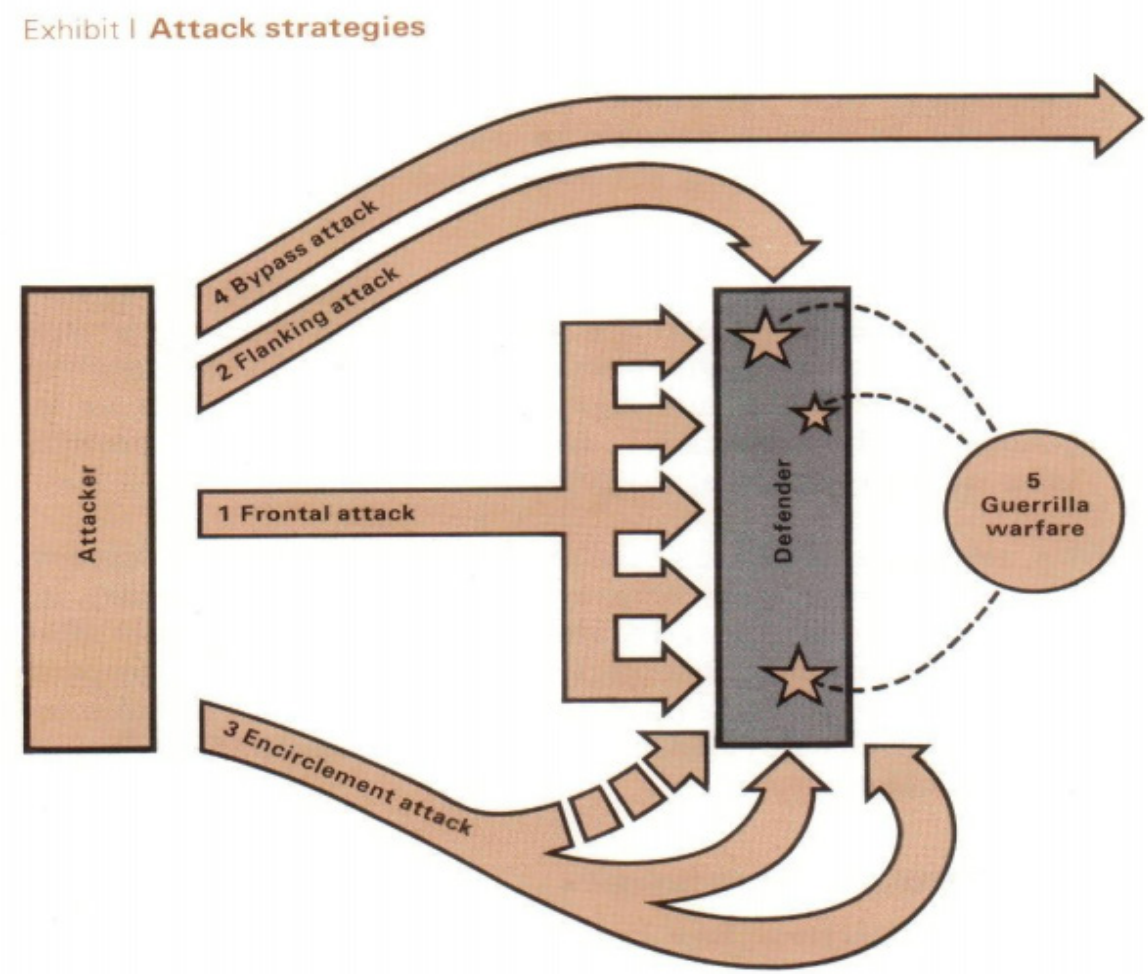

Source: Kotler and Singh (1981, p. 68) 
The hierarchy of marketing strategies was systematized by means of military literature by Kotler and Singh (1981) who described the strategies of marketing warfare in two dimensions - defensive and offensive. Offensive strategies are designed to achieve the marketing goals to increase the market share vis a vis the competition. In contrast, defensive strategies aim to maintain profitability, market position and protection of the market share (Bogdan, Gabriela, Alina, 2008). Kotler and Singh (1981) classed guerilla marketing under offensive strategies along with other strategies: (1) frontal attack; (2) flanking attack; (3) encirclement attack a and (4) bypass attack. Through their systematic and coherent approach, Kotler and Singh (1981) provide a more detailed examination of the offensive strategies compared to the previous literature (e.g. Odgen, 1999, Ries, Trout, 1997, Garsombke, 1987 in Bozkurt, Ergen, 2014). The offensive strategies, including the guerrilla attacks, are illustrated in Fig. 1. To further examine this issue, we provide a brief overview of the determined offensive strategies.

\section{Frontal attack}

The first and most risky marketing strategy is the frontal attack. In this type of strategy, the aggressor launches an all-out attack not on the weaknesses, but rather the strengths of its competitors (Kotler, Singh, 1981) in order to overwhelm the enemy and/ or competitive enterprise. The battle breaks out between two "large" enterprises: on the one hand it is the market leader, and the other the company, which aims to recover some of the market share of the market leader. Therefore, if the market leader is "major", even the attacker must be "big" (Ries, Trout, 1997). In an open battle, products, advertising, prices or distribution are compared side by side. The outcome of the battle depends on who has more strength or endurance (Kotler, Singh, 1981). According to the military doctrine, the success of a frontal attack is determined by the "principle of power", which says that the winning party is the one with more abundant resources. However, a rule applies that a successful frontal assault also depends on the attacker having three times more strength than its competitors (Bozkurt, Ergen, 2014), which emphasizes the need for the aggressor to have a strong advantage over the competitors. If the aggressor has less power than the defender and/or less power than what the military doctrine requires in the 3:1 rule in favor of the aggressor, the frontal attack resembles a suicide mission (Kotler, Singh, 1981). An example of the frontal attack in the marketing context is the decision to invest in research and development to reduce the production costs (Ries, Trout, 1997). Another alternative is comparative advertising, which is most often performed as a comparison of the prices of two competing products. This type of advertising attack was used e.g. by Lidl Slovakia against the competing chain Billa in 2019. In the advertisement titled "Why is Billa more expensive? Same products, but different prices", Lidl directly compared the prices of products sold under their brand with those of the said competitor. This way, the discount chain Lidl Slovakia directly confronted its main rival Billa. The confrontation was built on a review of objective facts by an independent research agency engaged in comparing common non-discounted selling prices (RM, 2019). Lidl claimed that identical goods purchased in the Lidl stores are cheaper and/or better priced than those in Billa.

It is obvious that the fight took place through objective facts on the conscious level of the consumers and the attack was launched at the cognitive elements of their attitudes. In this type of advertising, however, it is necessary to take legislation into account, which may legally restrict comparative advertising. In the case of comparative advertising in the above example, the frontal attack was legitimate and successful. 
Figure 2: Comparative advertising - Lidl, Billa, 2019

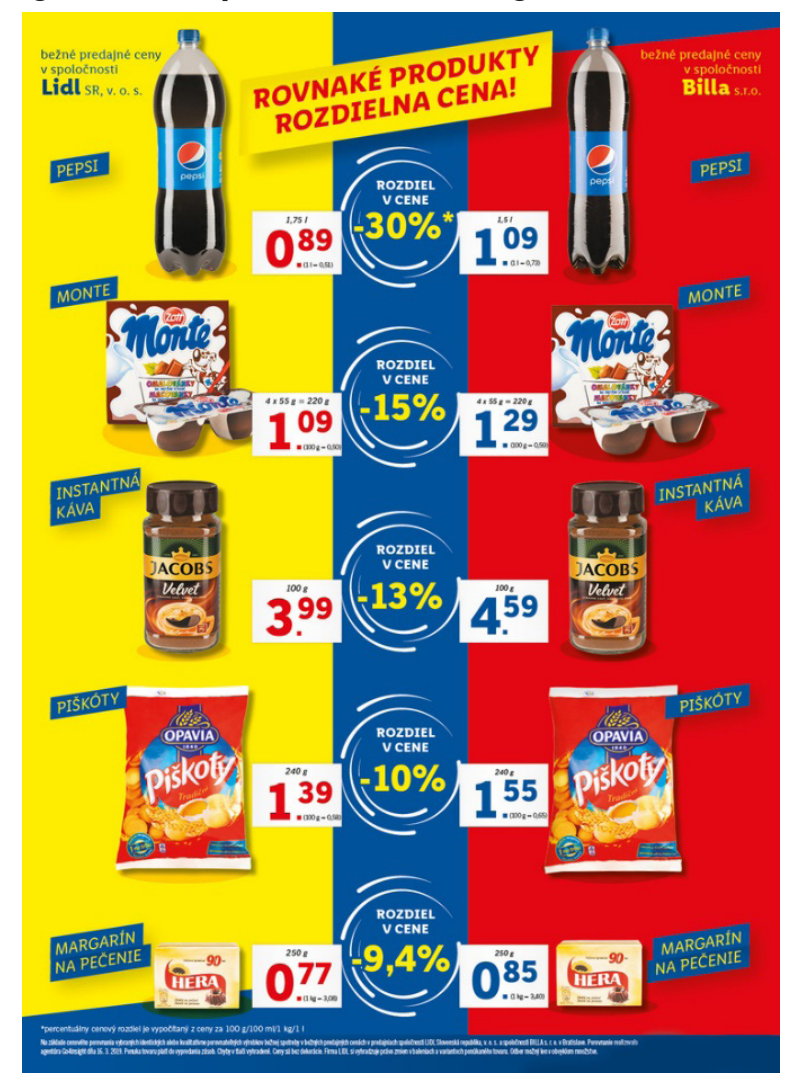

Source: RM. (2019)

In connection with the price attack, which is the most common type of frontal attack, Kotler, Singh (1981) claim that a frontal attack is successful if the market competitor does not respond with a mere lowering of the price, and the product is either identical with a differential price, or lower price and an identical value. In the frontal confrontation with the food chain Lidl Slovakia, Billa lost the battle because it tried unsuccessfully to reciprocate the frontal assault by downplaying the Lidl meat products, which, according to Billa, are exclusively from Poland. This way, Billa sought to lower the value of the Lidl brand because the Polish meat products generally carry a lower quality in the mind of consumers, and thus have a lower value for the consumer. The misleading information against Lidl, which has meat products from different countries, resulted in another dispute between the competitors.

In the context of offensive strategy and/or frontal attack, Ries and Trout (1997) add that it is difficult to overtake the market leader due to the implementation of its defensive positions. For many companies, insufficient resources can result in losing the battle with the market leader when the frontal attack method is used.

\section{Flanking attack}

Since not all companies are strong enough to successfully challenge their competitors in a frontal attack, the use of other marketing strategies based on the military context may seem appropriate - side, parallel or flanking attack. The essence of this strategy lies in the idea of avoiding an all-out frontal attack (Ries, Trout, 1997) and attack the weak spots of the imaginary army, which is typically the sides or the rear (Bozkurt, Ergen, 2014; Kotler, Singh, 1981). Even for this reason, the vulnerabilities (competitor's weaknesses) become the natural places of the aggressor's attack. The principle of the fight is then focused on the attack against the enemy's weaknesses (Kotler, Singh, 1981).

According to Ries and Trout (1997), this type of strategy is suitable for those companies that are not able to direct their resources to attack the competition directly. Avoid- 
ing a direct confrontation with the competitors, the flanking attack strategy is particularly attractive for companies with more limited resources than the competitive opponents (Bozkurt, Ergen, 2014). Kotler and Singh (1981) claim that if a company cannot overwhelm its competitors with brute force, it can deceive them by using the flanking attack strategy, which basically has two forms - geographical and segmentational.

In the first case, the intention of the company is to "attack" those geographic areas where competition has not taken root yet, or does not have a high share (Kotler, Singh, 1981). The second case illustrates the "attack" on those segments that the competition has not serviced yet. It only focuses on the resulting market gaps and an effective fulfillment of their needs and wishes with the intention to develop this market space into a strong consumer segment (Kotler, Singh, 1981). An example is the introduction of a product with different positioning than the competitive products (Ries, Trout, 1997).

When applying the strategic framework, a flanking attack should be focused on the narrowest aspect possible, which allows the challenger to concentrate its forces and resources in one narrow area. - e.g. on one product rather than a wide range of products. For example, FedEx attacked its competition by focusing its strength on one area - and began shipping the goods on the following day. The very slogan - The World on Time and the marketing communications showing the flexibility and promptness of delivery by the company regardless of the place of delivery, was adapted to this strategy.

Figure 3: Advertising of FedEx, 2016

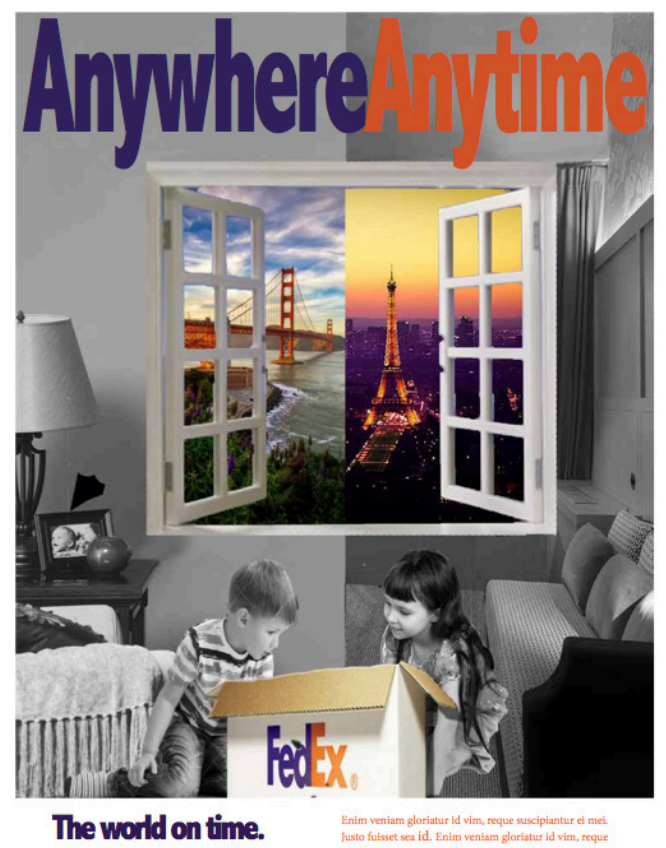

Source: Armanini, (2016).

The success of FedEx is also analyzed by Ries and Trout (1997), adding that the flanking attack strategy is effective only if the company tries to differentiate from the competition in one product, which greatly satisfied the needs of all consumers in the target market. The challenger then has a chance to win as a market leader in the minds of the consumers in this narrower class of products.

According to Ries and Trout (1997), the company should comply with certain principles for the effective implementation of the said strategic principle:

a. target the given segment with a new product category that does not compete di- 
rectly with the leading companies on the market. It does not necessarily have to be a new product. It is enough that the product is sufficiently different to consolidate its own position. The accompanying offensive moves may then be focused on different areas of product differentiation, such as low or high cost, product size and differentiation through distribution channels.

b. it is important to maintain the element of surprise for the competing company not to amass the required and considerable resources for an open marketing battle. To maintain the element of surprise, the test marketing should be minimized according to the authors.

c. after the surprising flanking attack, it is necessary to focus on securing its position on the market because it is very likely that the competition will be directed to bringing competitive products in the near future.

In the case of failure to observe the above conditions, the marketing strategy will not be successfully implemented. Moreover, in the opposite case, the flanking attack strategy might change into a frontal attack with losses that may lead to the elimination of the challenger. The above authors add that should the company not have sufficient funds to consolidate its newly acquired position, it is suitable to use the guerrilla strategy. It is clear from the above characteristics that the accompanying attack is not a direct attack on the market leader, but rather an attack in the areas where the leader has not consolidated a strong position (Ries, Trout, 1997). This results in covering various market needs (Kotler, Singh, 1981). According to Bozkurt and Ergen (2014), the flanking attack strategy is one of the strongest traditions of modern marketing philosophy with a greater chance of success than frontal attacks. Nevertheless, even the flanking attack carries a relatively high risk since the degree of adoption of innovative products on the market is unknown. Test marketing is constrained to a minimum in this respect since it is necessary to maintain the element of surprise. If successful, flanking attacks have the potential to build a "better" position in the market before the established market players can respond (Ries, Trout, 1997).

In connection with the frontal and flanking attack, Ries and Trout (1997) offer another alternative to the offensive strategy in which the attacker should not just focus on finding the weaknesses of the leading competitor, but the "weaknesses" in the competitor's strengths. The reason is that the market leader usually has sufficient resources to defend against an attack directed at its weaknesses. An example is when a market leader offers its product at a premium price, which may appear to be a weakness. When an attack is made on this kind of "weakness" and the price is reduced by the competitors, the market leader usually has a large enough profit margin to lower the price to the necessary level and defend its position. Therefore, the above authors claim that it is important to focus on the key weaknesses, and/or disadvantage of the competitor's strengths, which is not mentioned in other resources dedicated to marketing strategies (cf. Bozkurt, Ergen, 2014; Kotler, Singh, 1981). The disadvantage or weakness of the competitor's strengths or competitive advantages is often linked to a significant investment in assets, which are more difficult to adapt.

\section{Encirclement attack}

In addition to the strategic frameworks mentioned above, businesses can also use an encirclement strategy to achieve success. (encirclement). While in the previous attack strategies the competitor has been confronted with a rather indirect challenge, the encirclement strategy sees the competitor from several directions. The encirclement attack involves the launch of a considerable offensive against the enemy, attacking several areas of the competitor, and resulting in the competitor simultaneously defending its front, side and rear (Bozkurt, Ergen, 2014; Kotler, Singh, 1981). The successful implementation of a marketing strategy results in the fragmentation and differentiation of 
the competitor's segment and the related challenging of consumer loyalty to the brand (Kotler, Singh, 1981). The use of this strategic framework only makes sense if the attacker is able to gather resources better than the primary competitor, provided a rapid and complete attack is launched. If empty niches cannot be created through the diffusion of segments, the encirclement attack is then transformed into a frontal attack and as such should comply with the 3:1 rule for success in the battle with firepower (Kotler, Singh, 1981). Examples in the field of marketing include the production of different product variants with a focus and effort to reach the same consumers as the competitor (Bozkurt, Ergen, 2014).

\section{Bypass attack}

A military attack resembling the cold war in the time of peace is dubbed a bypass attack in the military and marketing strategies. Instead of an open military conflict, it is more of an indirect attack in which "agreements" of sorts are formed about the future prospects in the confrontation zone. According to Kotler and Singh (1981), it is the most indirect offensive strategy because the attacker avoids all aggressive moves directed against the segments in the existing market space of the competitor. In principle, the bypass attack strategy can be carried out in two ways: diversification in unrelated products or entry into the new geographic markets for existing products (Bozkurt Ergen, 2014; Kotler, Singh 1981).

The marketing strategy based on the bypass attack was used by Tchibo, which has been active on the Slovak market as a producer of coffee and coffee products for a long time. To distinguish itself from the competitors, the company decided to include other and quite unrelated - products in its portfolio, including clothing, sports equipment and appliances (Tchibo, 2020). In this vigorous step, the company has expanded its product range to include a new category of products not provided by its direct competitors. Below is an example of sports equipment sold on the website of this coffee producer.

Figure 4: Tchibo Website

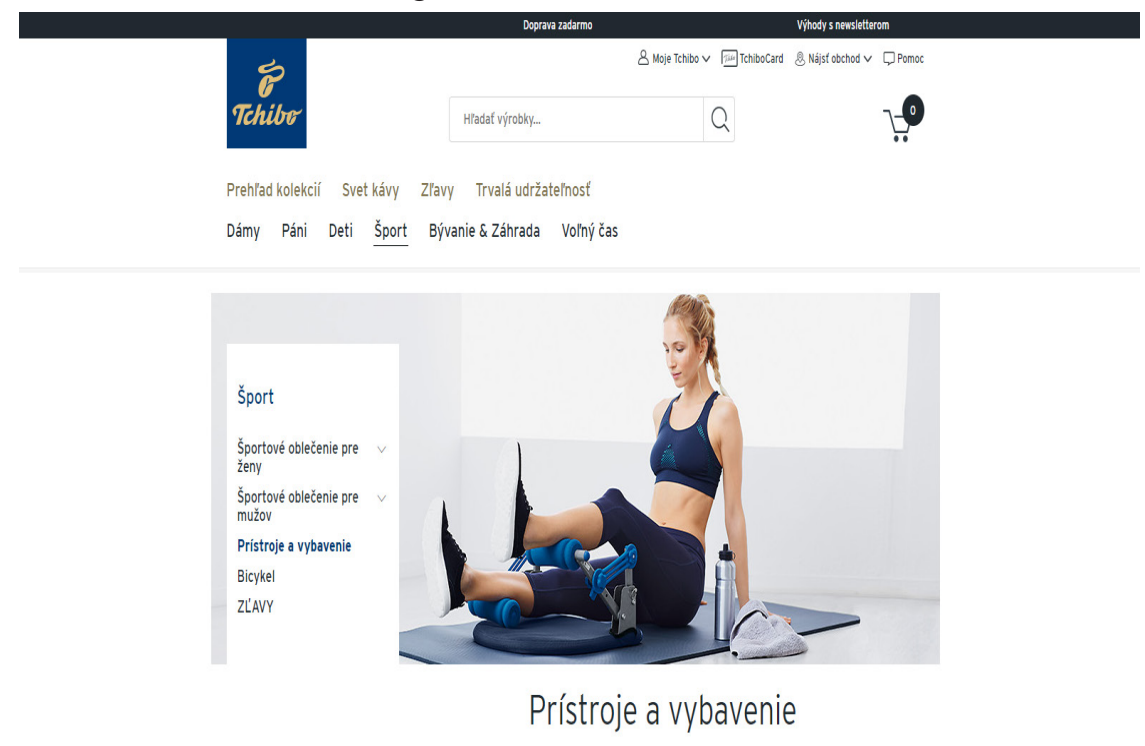

Source: Tchibo. (2020)

\section{Guerilla attack}

Unlike other offensive strategies, guerrilla warfare is used by the companies that are too small to launch an offense or accompanying moves compared to the other competitors in the market. For example, if a small business implements a flanking attack strategy against a more sizable competitor, the competitor could use a similar strategic 
principle and even gain significant funds, resources and a greater part of the market share, and the challenger would suffer a significant loss (Ries, Trout, 1997). Therefore, guerrilla warfare is the only key to success in the market for small businesses.

According to Bozkurt and Ergen (2014), the guerrilla warfare strategy in marketing is the most appropriate strategy for small but high-end enterprises with a limited financial budget. These small companies are able to identify a large enough segment to be attractive for them, but small enough to attract larger competitors (Ries, Trout, 1997).

The very guerilla aspect is used, which is based on the context of military strategies and/or the definition of guerrilla warfare. The principle of guerrilla warfare is based on weakening the enemy with a series of smaller attacks. The attacks are directed at the weak spots of the enemy and carried out in a selective manner (Bogdan, Gabriela, Alina, 2008). These small but sporadic attacks alternate with successive withdrawals (Bogdan, Gabriela, Alina, 2008; Kotler, Singh, 1981).

In a figurative sense, the guerilla strategy was first used in marketing and/or marketing strategy by Jay Conrad Levinson in 1984 (Bigat, 2012). Levinson claims that the principle of guerilla marketing lies precisely in the guerrilla attacks, withdrawals from combat and their repetition with a focus on the benefits of specific products or services (Levinson, 2003). When using the guerrilla strategy, the attack is directed at various aspects and/or "territories" of the opponent to harass and demoralize the competition (Kotler, Singh, 1981). In a practical sense, the implementation of the guerrilla strategy entails e.g. selective price reductions, pressure on management and intense bursts of advertising (Kotler and Singh, 1981). The principle of guerrilla warfare in marketing can be used in various ways. Bogdan, Gabriel, Alina (2008) claim that in addition to the above-mentioned selective price cuts, it may also include an aggressive form of advertising: short-term alliances or negative publicity.

Within the principle of guerrilla warfare, which is suitable for small businesses, the "small enterprise" tag is transformed into an advantage because a small company with a high degree of flexibility (unlike large corporations) can be easily withdrawn from the market or change its product lines and management objectives (Bogdan, Gabriela, Alina, 2008). The above is also highlighted by Bigat (2012) who says that the guerrilla tactics is rational and able to transform its disadvantages into advantages.

The campaign to promote the movie Ex-Machina on the market is an example of guerrilla marketing in the digital environment. The guerilla campaign was held during the SXSW show in Austin, Texas where more than a hundred thousand people convened in this period (Warren, 2015). The marketing team created Ava's profile in the Tinder dating application. Ava is one of the main characters in the movie Ex Machina - she acts as a human being but is driven by artificial intelligence in her nature. Her aim was to understand human thinking and behavior and use this information to her benefit. 
Figure 5: Guerilla marketing: Ex-Machina

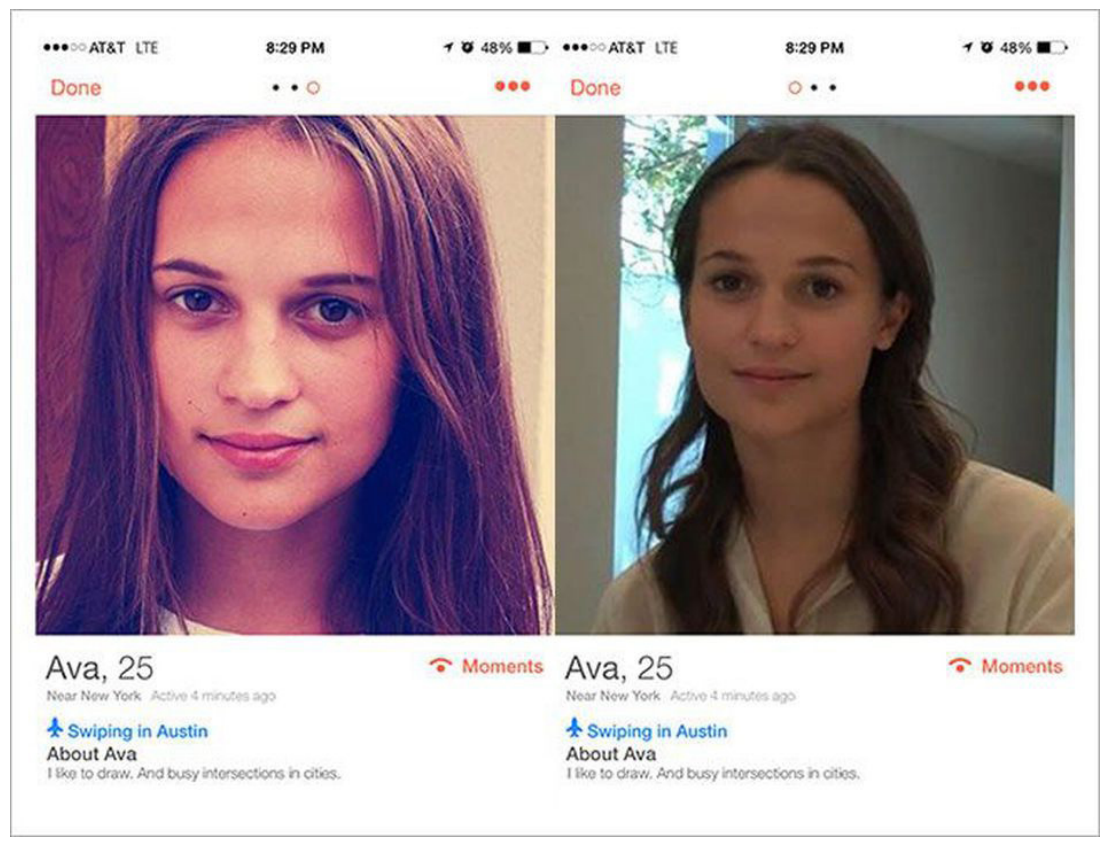

Source: Warren (2015).

In this campaign, the users could have a genuine conversation with artificial intelligence on Tinder, and the questions they received from the Tinder bot were similar to the ones Ava was asking in the movie. When opening Ava's profile, the users could only see one photo and one video. These promoted the movie Ex-Machina, which was screened in Austin at that time. This example illustrates the perfect link between the dating campaign and the movie about artificial intelligence and complex human relationships (Warren, 2015). Although the campaign is in essence balancing on the edge of ethics and legality, it aroused the curiosity in the potential movie-goers - typically in the SXSW festival audience - and increased the screening profits. It also unleashed a turbulent online debate between the people and in the news. The campaign became viral on the Internet.

\section{Conclusion}

The existence of apparent similarities between the nature of warfare and the nature of the market, the professional public views the commercial sector as a battleground for the competing companies. In this spirit, the market space is formed by constant battles between the individual enterprises, and success is only possible with the help of appropriate marketing strategies, which is the driving force for the companies to vanquish their rivals. The aim of our paper was to identify usable marketing-communication strategies and grasp guerilla marketing in a broader context based on the marketing-communication strategy, which is inspired by the military strategy of a guerilla attack. Thanks to the systematization of theoretical knowledge and metaanalysis of expert literature, we have identified five attack strategies: (1) frontal attack; (2) flanking or side attack; (3) encirclement attack, (4) bypass attack, and (5) guerilla attack.

The systematization and specification of these strategies is beneficial on the theoretical and practical level. From the theoretical perspective, it illustrates the existing basic marketing strategies, thus participating in the extension of the theoretical corpus. From the practical perspective, the knowledge of marketing strategies on the background of military strategies is crucial for the proper understanding of marketing in a given commercial or non-profit company.

The selection of a marketing strategy based on the context of war and war strategies constitutes one of the essential steps when the decisions are made on how to 
compete against other businesses. Ultimately, this selection is crucial for the success or failure of a company in the market environment.

It turns out that the guerilla strategy and/or guerilla marketing is an effective way for the small businesses to fight the large ones. When using the guerrilla strategy, the attack is directed at various aspects and/or "territories" of the opponent to harass and demoralize the competition (Kotler, Singh, 1981). The guerilla warfare is characterized by a series of small but occasional attacks/skirmishes and the subsequent withdrawal, which is considered a weapon of guerrilla marketing (Jurášková, Horňák, 2012) and its typical characteristic element. In addition to the "partisan" aspect in the fight against competition, the guerilla marketing is also characterized by other features. According to expert literature, guerilla marketing is described as unconventional and/or untraditional, cost effective, surprising, original and creative, provocative and cheeky, flexible, unusual, humorous, magnificent, contagious (Nufer, Bender, 2008, Nufer, 2013). While the above adjectives describe a range of characteristics of the guerrilla strategy, its most typical hallmark is a series of small intermittent attacks and withdrawals. This fight is unraveling alongside the existing conflict, and it revolves around the intention of the weaker business to start the fight as a challenger. With an effort to avoid the negative aspects of guerilla marketing, the guerilla warfare is gradually disappearing from the commercial sector and it is adopted by social advertising, which uses it to highlight the negative social phenomena, engage the participants and effectively shape their attitudes.

\section{Acknowledgement}

This study is a partial output from the research project APVV-18-0257 - "Incubator of Multimedia Digital Production - Reciprocal Transfer of Science, Art and Creative Industries"

\section{References}

ARMANINI, A. (2016). Fedex print ad revision. [online: October 12, 2019]. Available online: https://amanndaarmaniniblog.wordpress.com/2016/01/29/fedex/

BIGAT, C. E. (2012). Guerrilla advertisement and marketing. [in:] Procedia - Social and Behavioral Sciences, 51, (2012), 1022 - 1029. doi: 10.1016/j.sbspro.2012.08.281

BOGDAN, C. G.; GABRIELA, C. L.; ALINA, C. (2008). To the edge of marketing warfare. Applying military strategies in a company from the mobile telecommunication sector in romania. [in:] Economic Science Series, 17 (4), 2008. s. 155-159. Available online: http://steconomiceuoradea.ro/anale/volume/2008/v4-management-marketing/024.pdf

BOZKURT, F. ERGEN, A. (2014). Art of War and Its Implications on Marketing Strategies: Thinking like a Warrior. [in:] International Journal of Research in Business and Social Science (IJRBS), 3 (3), 2014. p. 37-47. ISSN: 2147-4478.

GUPTA, M.; KAUR, K.; KAMBOJ, A. (2014). Guerilla Marketing: Its Happening. [in:] IJITKM Special Issue (ICFTEM-2014), (5), 2014. p. 206-213. ISSN 0973-4414. Available online: <https://pdfs.semanticscholar. org/5a73/7767c6cda8718dedb10968238b4766e100d1.pdf>.

KOTLER, P; SINGH, R. (1981). Marketing Warfare in the 1980s. 1981. p. 62- 81. [online: October 12, 2019]. Available online: https://edisciplinas.usp.br/pluginfile.php/4469844/mod_resource/content/0/KotlerSingh.pdf JURÁŠKOVÁ, O., HORŇÁK, P. ET AL (2012). Velký slovník marketingových komunikací (Dictionary of Marketing Communication). Issue 1 Praha: Grada Publishing, 2012. 272 p. ISBN 978-80-247-4354-7.

LESÁKOVÁ, D. ET AL., (2001). Strategický marketingový manažment (Strategic Marketing Management). Issue 1 Bratislava: Sprint vfra, 2001. 339 p. ISBN 80-88848-90-3.

LEVINSON, J. C. (2003). Guertilla Marketing in a Tough Economy: To succeed during an economi rough path, you have to think and act like a successful guerilla marketer. [online:

October 12, 2019]. Available online: https://www.entrepreneur.com/article/65486 
LEVINSON,, J. C. (2011). Guerilla marketing: nejúčinnější a finančně nenáročný marketing (Guerilla Marketing: The Most Effective and Financially Non-Demanding Marketing). Issue 2. Brno: Computer Press, a.s., 2011. 326 p. ISBN 978-80-251-3546-4.

NUFER, G.; BENDER, M. (2008). Guerilla Marketing, Reutlinger Diskussionsbeiträge zu Marketing \& Management, No. 2008-05, Hochschule Reutlingen, ESB Business School, Reutlingen. [online: October 12, 2019]. Available online: <https://www.econstor.eu/bitstream/10419/57387/1/680096272.pdf>. ISSN 1863-0316

NUFER, G., 2013. Guerrilla Marketing-Innovative or Parasitic Marketing? [in:] Modern Economy, 2013, 4, 1-6. [online: October 12, 2019]. Available online: http://dx.doi.org/10.4236/me.2013.49A001

OGDEN, M. (1999). Master four strategies of marketing warfare. [in:] Jacksonville Business Journal. [online: October 12, 2019]. Available online: https://www.bizjournals.com/jacksonville/stories/1999/01/18/smallb3.html

RIES, A.; TROUT, J. (1997). Marketing Warfare. New York: McGraw-Hill Education; 1st ed. 1997. 224 p. ISBN-13: 978-0070527263.

RM. (2019). Lidl pokračuje v kampani proti Bille. Porovnal aj ceny značkových výrobkov (Lidl continues its campaign against Billa. It even compared the prices of branded products). [in:] Strategie HNonline. [online: October 12, 2019]. Available online: https://strategie.hnonline.sk/marketing/1922730-lidl-porovnava-svoje-ceny-scenami-v-bille-ta-to-povazuje-za-zavadzaciu-reklamu

SPÁLOVÁ, L. - WOJCIECHOWSKI, Ł. (2017). Nové formy politického jazyka - guerillové politické kempane (New forms of political language - political guerilla campaigns). [in:] Štefančík, R. (ed.): Jazyk a politika: na pomedzí lingvistiky a politológie II. Bratislava: Ekonóm, 2017, pp. 124-132. ISBN 978-80-225-4424-5.

TCHIBO. (2020). Prístroje a vybavenie (Tools and equipment). [online: May 12, 2020]. Available online: https:// www.tchibo.sk/sport-pristroje-vybavenie-c400049091.html

WARREN, CH. (2015). 'Ex Machina' viral marketing campaign trolls Tinder while winning SXSW. [online: May 12, 2020]. Available online: https://mashable.com/2015/03/16/ex-machina-tinder-marketing/?europe=true 